\title{
The Adverb antea in the Treatises of Tacitus
}

\author{
By Tikva Zadok
}

\begin{abstract}
In studies on Latin adverbs (e.g., Menge 1961, Bos 1967, Löfstedt 1967, Pinkster 1972) the discussion of a specific temporal adverb in a certain corpus is rare. Moreover, an adverb peculiar to the treatises of Cornelius Tacitus (55-56 until the second decade of the second century A.D.) has not yet been analyzed in the studies concerning his language and style (e.g., Draeger 1882, Voss 1963). Our study fills a gap, to a certain extent, in the researches on the adverbs in Latin prose in general and in the corpora of Tacitus in particular, by examining the characteristic and unique usages of anteā in his treatises regarding content and style. We surveyed selected studies dealing with both general and specific adverbs, as well as with the language and style of Tacitus. The grammatical approach adopted here is descriptive. It offers a thorough analysis of a specific adverb (antea) in the prose opus of one author (Tacitus), which is necessarily a restricted and fairly homogeneous corpus. This enables us to present the full documentation of the adverb under discussion in the selected corpus. Our main conclusions are: Anteā occurs mostly with contrasting temporal adverbs denoting posteriority/anteriority in relation to the past. Its modified part of speech is only explicit and is mostly a finite verb in past tenses, due to the meaning of anteā. In few cases antea modifies more than one part of speech in a clause. Its prevalent position is after the modified element. A concluding comparison of anteā yielded identical and different features alike.
\end{abstract}

\section{$[0]^{1}$ The Purpose of Our Research and Its Contribution}

The purpose of our research is to exemplify by means of a detailed linguistic analysis the usages of antea in the treatises of Tacitus. The need for this kind of research arises from the paucity of comprehensive research on a specific adverb in a certain corpus of Latin prose and the lack of quotations on adverbs from the Tacitean corpora in the secondary literature. Moreover, no comprehensive analysis of a specific adverb occurring in the treatises of Tacitus is contained in the studies concerning his language and style. Our study fills a gap, to a certain extent, and contributes to the researches on adverbs of Latin prose in general and in the corpora of Tacitus in particular. This is achieved by examining the characteristic and unique usages, including content and style of a specific adverb in his corpora.

Pinkster (1972) emphasizes the need for further studies on adverbs. In his opinion, the syntactical characteristics of adverbs and the structures in which they occur have not been sufficiently examined. Therefore, it is necessary to carry out similar studies of additional types of adverbs in a specific corpus. The investigation of this subject with an exhaustive discussion in a given corpus will contribute to its study and further it.

We surveyed selected studies dealing with adverbs in general and specific adverbs, as well as with the language of Tacitus and his style (see §§0.1-0.2 below). Our grammatical approach adopted here is descriptive, including

\footnotetext{
* Former Post-doctoral Fellow, Tel Aviv University, Israel.

${ }^{1}$ In order to facilitate the best possible organization and readability of this paper, headings and subheadings have been listed with a numbering system, rather than traditional titles, and are referenced as such throughout the work.
} 
quotations from the corpora in question, in order to clarify and illustrate the phenomena with literal translations, wherever applicable.

The analysis of ante $\bar{a}$ in the points indicated in 1-5 below is described at length with detailed comparative tables (see $\S \S 1-5$ and Tables 1-5). This is in contrast to the studies mentioned in $\S \S 0.1-0.2$ below, where the following points were not sufficiently discussed. The structure of the discussion to come is thus as follows:

1) The distribution of antea in each book, its meaning and variants;

2) Its proximity to an additional adverb (temporal/negative/manner/measure adverb) or without it and the temporal adverbs denoting posteriority/anteriority in relation to the past with antea ;

3) The part of speech modified by the adverb in the sentence: mostly a finite verb in past tenses, due to the adverb's meaning (perfect, imperfect, pluperfect [+ adverb]), participium in P.P.P., adjective, infinitive [+ adverb], cases in which ante $\bar{a}$ modifies more than one element in a clause/sentence;

4) Its position in relation to the part of speech modified by it in a clause/ sentence (in first/second/third position and further removed one before/after the modified element, two positions of anteā concerning its modified elements). In this context we examined the linguistic and stylistic means employed by the author (where some message is to be highlighted, word order, anaphora, a chiastic structure or a parallel one [mainly by contrasted pairs of words], a detailed classification on the adverb's position in a clause with phrases, other adverbs, etc.);

5) A concluding comparison with identical and different features of antea between Tacitus' books. Phenomena, which are peculiar to the adverb in one of his books, do not necessarily occur in his other ones, because each book has features of its own, which are influenced by its content and style; and

6) Conclusions.

\section{[0.1] Selected Studies on Latin Adverbs (in Chronological Order)}

\section{[0.1.1] Studies dealing with adverbs in general}

1) Menge (1961: 313-33, $\S \$ 461-498)$ concerns the adverbs' meanings; phrases with similar meaning to the same adverb; adverbial suffixes; verbs, adjectives or other adverbs, which are modified by an adverb; 2) Löfstedt (1967) discusses at length the frequency of the adverbs' morphemes, nouns and adjectives in masc./neutr. sg. which are used in certain contexts as an adverb (prìmum, sōlum, etc.) and the modified part of speech in general; 3) The monumental study of Pinkster (1972) "On Latin Adverbs" (see also §0 above) contains a critical discussion of the adverbs' treatment in Latin studies, a description of their functions in larger constructions, classificatory problems, the relationship between adverbs and other uninflected words, and the syntactic characteristics of adverbs and other constituents (adverbial adjuncts, etc.). His study is based mainly on the works of Cicero, somewhat on Vergilius, Plautus and Julius Caesar, but without quotations from Tacitus' books; 4) Devine and Stephens (2006) "Latin Word Order" deal with word order in a clause/sentence in general without a detailed analysis of a specific adverb in a certain corpus. 
[0.1.2] Studies dealing with specific adverbs

1) Booth (1923) deals only with the position of measure adverbs in Roman comedy and in de Agri Cultura by Cato; 2) Lundström (1961) concerns abhinc and ante (with acc./abl. and with measure adverb in abl./acc.) without relationship to a specific corpus; 3) An exhaustive discussion on prae and pro as adverbs, prepositions and prefixes is offered by Francis (1973: 1-59); 4) Risselada (1996: 105-125) deals with the functions of nunc (as a discourse marker [including its phrases with at, sed, tamen, vero] and as a temporal complement) as compared to now in English.

\section{[0.2] Selected Studies on the Language of Tacitus and His Style}

1) Draeger (1882: 5, 8-9, $\S 8,21-24)$ deals with the syntax and style of Tacitus. He discusses briefly the usages of the adverbs in his treatises; 2) Mendell (1911) gives a detailed analysis on sentence connection in Tacitus; 3) Voss (1963) discusses the emphatic style employed by Tacitus.

\section{[1] The Distribution of Antea in the Corpora ${ }^{2}$, Its Meaning and Variants}

Anteā (consists of ante $+e \bar{a}$ ) occasionally occurs in Old Latin (Kühner and Stegmann 1962, 2/1: 576, §111a). It is documented in 19 instances: 13 in Ann. and six in Hist. It does not occur in the minor works Ag., Ger. and Dial. (Table 1) ${ }^{3}$.

Ante $\bar{a}$ is used for one description ${ }^{4}$ as a temporal adverb with the meaning "previously, before" in different contexts. Other synonymous adverbs with antea are used as: 1) An adverb or adjective (such as ante, antīquitus, quondam); 2) An adverb of time and place (e.g., aliquandō); 3) Some synonymous adverbs with more than one meaning (ōlim, etc.). The alternative usages of these synonymous adverbs are, inter alia, for variety and also stylistic characteristics of the author [for synonymous words in Latin see Calboli 1965, 1989, Menge 1961, 1988].

The reading antea $\bar{a}$ is documented in the corpora with three variants, mostly with ante:

A. Ante se (instead of anteā) egerint: Tac. Hist. 3,2,1 (Fisher 1911: 115). According to Heraeus (1929: 2), Tacitus more often employs agere without se, mostly with an adverb and rarely with an adjective. Se agere for agere is rarely found in late period (Simcox 1876: 2).

B. Ante: Tac. Hist. 4,1,3 (Koestermann 1969: 162); Ann. 16,3,2 (Römer 1976: 121).

C. Ante ea: Tac. Hist. 4,86,2 (Fisher 1911: 228).

\footnotetext{
${ }^{2}$ The quotations for discussion in the corpora are according to the editions of Heubner 1978, 1994. Slight changes are according to Fisher 1906, 1911, Koestermann 1969, 1971, Weiskopf 1973, Römer 1976.

${ }^{3}$ Gerber and Greef 1877-1890, 1: 84-85, s.v anteā; Blackman and Betts 1986, 1: 138.

${ }^{4}$ On adverbs, which are used for several descriptions, see, e.g., Pinkster 1972, Menge 2000. Their discussion is mainly on adverbs of manner, which denote measure in certain contexts, without parallels from the corpora.
} 
Table 1. The Distribution of Anteā in the Corpora in Descending Order ${ }^{5}$

\begin{tabular}{|l|c|c|}
\hline $\begin{array}{l}\text { The } \\
\text { Treatise }\end{array}$ & \multicolumn{1}{|c|}{ References } & $\begin{array}{l}\text { No. of } \\
\text { Cases }\end{array}$ \\
\hline Ann. & $\begin{array}{l}1,3,3 ; 2,87,1 ; 4,2,1 ; 6,1,2 ; 11,1 ; 16,1-2 ; 36,2 ; 12,50,2 ; 60,1 ; \\
13,15,5 ; 14,20,2 ; 28,1 ; 16,3,2 \text { (var. ante) }\end{array}$ & 13 \\
\hline Hist. & $\begin{array}{l}3,2,1 \text { (var. ante se); 37,2;58,3;4,1,3 (var. ante); } 75,2 ; 86,2 \\
\text { (var. ante ea) }\end{array}$ & 6 \\
\hline Ag. & - & - \\
\hline Ger. & - & - \\
\hline Dial. & - & $\mathbf{1 9}$ \\
\hline \multicolumn{2}{|l|}{ General Total }
\end{tabular}

\section{[2] Anteā in Proximity to an Additional Adverb or Without It}

In eight instances ante $\bar{a}$ occurs without proximity to an additional adverb, whereas in 12 instances it is in proximity to an adverb (for emphasis, contrast, etc.), a phenomenon which reflects the contents and style of the treatises: A. Temporal adverb (6x); B. Validity adverb in negative (3x); C. Manner adverb (2x); D. Measure adverb (1x). In three instances (Tac. Ann. 6,1,2; 16,1-2; 16,3,2) more than one adverb are next to antea .

\section{[2.1] Anteā in Proximity to an Additional Adverb}

\section{[2.1.1] Temporal adverb ${ }^{6}$}

\subsubsection{Posteriority in relation to the past with antea}

2.1.1.1.1 Anteā ... tunc

Quin et Caesarem se dici voluit, aspernatus anteāa, sed tunc superstitione nominis, et quia in metu consilia prudentium et volgi rumor iuxta audiuntur. "Moreover, (Vitellius) even wished to be called Caesar, (a title), which he had formerly rejected, but then through a superstition about the title (he accepted it), and because in time of fear the counsels of the wise men and the gossip of the crowd are listened to in like manner" (Tac. Hist. 3,58,3).

\subsection{Tandem ... anteā ... tunc prīmum}

Nam Bassus, effosso agro suo latisque circum arvis, dum hunc vel illum locum promissi specus adseverat, sequunturque non modo milites, sed populus agrestium efficiendo operi adsumptus, tandem posita vaecordia, non falsa anteā somnia sua seque tunc primum elusum admirans, pudorem et metum morte voluntaria effugit.

"For Bassus dug up his own land and wide plains around (it), while asserting that this or that (was) the place of the promised cave, and not

\footnotetext{
${ }^{5}$ In the references were indicated the author, treatise and book number followed by the number of chapter and paragraph (Tac. Ann. 4,2,1; Hist.3,37,2, etc.).

${ }^{6}$ For antea, which occurs with additional contrasting temporal adverbs in other corpora, see L.Sh., p. 129b, s.v. anteā, temp. adv., I-III; OLD, p. 138b, s.v. anteā, adv., b-c.; TLL 1/2, pp. $137-$ 140, s.v. ante $\bar{a}$, I-II.
} 
only soldiers followed him, but (also) a populace of rustics engaged for carrying out the work. Finally his delusion was thrown off, (and saying) with amazement that his dreams had never before been false and that then for the first time he had been deceived (by them), he escaped humiliation and fright by suicide" (Tac. Ann. 16,3,2).

Antea is anterior to tunc primum, while tandem is posterior to antea and tunc prīmum.

2.1.1.1.2.1 Tuncque prīmum ... anteā: see Tac. Ann. 6,1,2, \$4.2.1, ex. 5 below.

2.1.1.1.3 Anteā ... mox: see Tac. Ann. 6,11,1, §4.1.2, ex. 1 below.

2.1.1.1.4 Dein ... anteā: see Tac. Ann. 13,15,5, §3.2.1, ex. 2 below.

\subsubsection{Anteriority to anteā by ōlim}

Tac. Ann. 6,16,1-2 (see $\S 3 \cdot 1.3$ below): anteā is anterior to prīmō, dein and postremo, while olim is anterior to antea .

[2.1.2] Validity adverb in negative ${ }^{7}$

2.1.2.1 Numquam ante $\bar{a}$

Pridie kalendas Novembris Rosius Regulus iniit eiuravitque. Adnotabant periti numquam anteā non abrogato magistratu neque lege lata alium suffectum; nam consul uno die et ante fuerat Caninius Rebilus C. Caesare dictatore, cum belli civilis praemia festinarentur.

"On the 31st of October Rosius Regulus entered and resigned (his consulate office). Experts remarked that never before had another (consul) been elected, unless the office had been declared vacant and the passing of a law; for Caninius Rebilus had been even before consul for one day, during the dictatorship of Gaius Caesar, when rewards (for services) in the civil war were hurriedly distributed" (Tac. Hist. 3,37,2).

2.1.2.2 Nōn ... anteā: see Tac. Ann. 16,3,2, §2.1.1.1.2 above; 1,3,3, $\S 3.1 .1 .1 .1$ below.

\section{[2.1.3] Adverb of manner}

2.1.3.1 Ferōcius anteā: see Tac. Hist. 3,2,1, §3.1.1.1 below.

2.1.3.2 Temere anteā: see Tac. Hist. 4,75,2, \$4.3.2 below.

[2.1.4] Adverb of measure ${ }^{8}$ by et: see Tac. Ann. 2,87,1, §3.2.1, ex. 1 below.

\footnotetext{
${ }^{7}$ For the occurrence of ante $\bar{a}$ with negative adverbs in other corpora see L.-Sh., p. 129b, s.v.

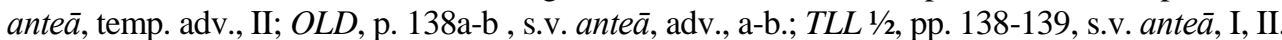

${ }^{8}$ For ante $\bar{a}$ with adverbs denoting measure (paulo/longe, etc.) in other corpora see $T L L 1 / 2$, p. 139, s.v. ante $\bar{a}$, II.
} 


\section{[2.2] Anteā without Proximity to an Additional Adverb}

Vacuamque ${ }^{9}$ rursus Armeniam Radamistus invasit, truculentior quam antea, tamquam adversus defectores et in tempore <re $>$ bellaturos.

"(And) Armenia, once more without a ruler, Radamistus invaded (it), more savage (now) than before, as if he facing rebels and who would, in an appropriate time, rise against him again" (Tac. Ann. 12,50,2).

For more references, see Table 2.

Table 2. Antea in Proximity to an Additional Adverb or Without It

\begin{tabular}{|c|c|c|c|}
\hline With an Additional Adverb & References & $\begin{array}{l}\text { No. of } \\
\text { Cases } \\
\end{array}$ & Total \\
\hline 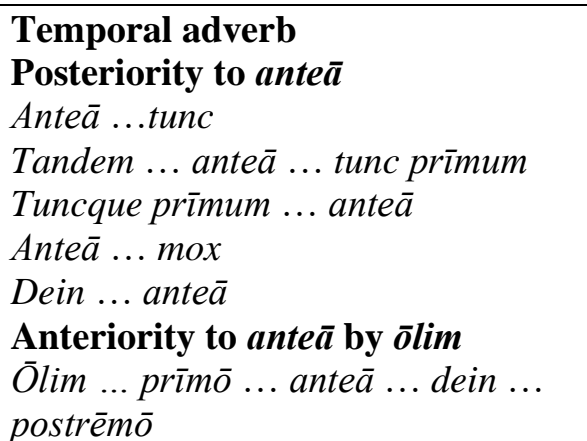 & $\begin{array}{l}\text { Tac. Hist. } 3,58,3 \\
\text { Tac. Ann. } 16,3,2 \\
\text { Tac. Ann. } 6,1,2 \\
\text { Tac. Ann. } 6,11,1 \\
\text { Tac. Ann. } 13,15,5 \\
\text { Tac. Ann. } 6,16,1-2\end{array}$ & $\begin{array}{l}1 \\
1 \\
1 \\
1 \\
1 \\
1\end{array}$ & 6 \\
\hline 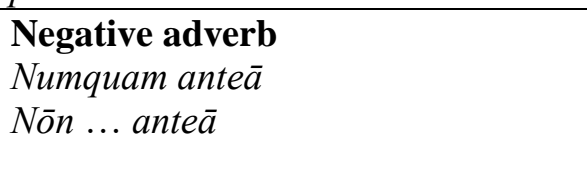 & $\begin{array}{l}\text { Tac. Hist. 3,37,2 } \\
\text { Tac. Ann. 1,3,3; } \\
16,3,2\end{array}$ & $\begin{array}{l}1 \\
2\end{array}$ & 3 \\
\hline 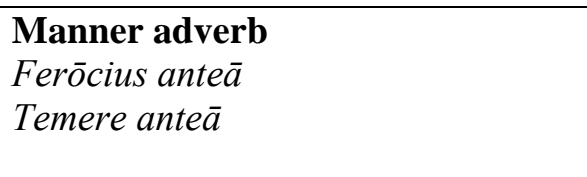 & $\begin{array}{l}\text { Tac. Hist. 3,2,1 } \\
\text { Tac. Hist. 4,75,2 }\end{array}$ & $\begin{array}{l}1 \\
1\end{array}$ & 2 \\
\hline Measure adverb by $e t$ & Tac. Ann. 2,87,1 & 1 & 1 \\
\hline Without an Additional Adverb & $\begin{array}{l}\text { Tac. Hist. 4,1,3; 86,2; } \\
\text { Ann. 4,2,1; 6,36,2; } \\
12,50,2 ; 60,1 ; \\
14,20,2 ; 28,1\end{array}$ & 8 & 8 \\
\hline
\end{tabular}

\section{[3] The Part of Speech Modified by Anteā in the Sentence ${ }^{10}$}

From Table 3, the modified element by antea is only explicit. It is mentioned in the clause, in which the adverb is included, while in three instances it is mentioned in the clause before the phrase $\underline{u t / q u a m}$ antea . The grammatical

\footnotetext{
${ }^{9}$ For vacuus meaning "having no ruler or governor" in this context see $O L D$, p. 2002 b-c, s.v. vacuus,-a,-um, 9.b.

${ }^{10}$ For the modified element by anteā in other corpora see L.-Sh., p. 129b, s.v. anteā, temp.

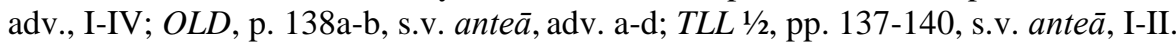


forms modified by it are as follows: $\underline{\mathbf{A}}$. Finite verb in past tenses $(6 \mathrm{x})$, due to the meaning of ante $\bar{a}^{11}$ : a) Perfect $(3 \mathrm{x}$; in $2 \mathrm{x}+$ adverb); b) Imperfect $(2 \mathrm{x})$; c)

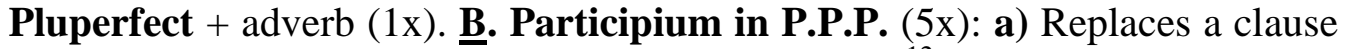
(4x); b) P.q.p. pass. without esse (1x). C. Adjective $^{12}(5 \mathrm{x})$ : a) Attribute (3x); b) Praedicativum $(1 \mathrm{x})$; c) Predicate noun with the copula esse $(1 \mathrm{x})$; $\underline{\mathbf{D}}$. Inf. perf. pass. (without esse): predicate of $\mathrm{AcI}(3 \mathrm{x})$ : a) + inf. complement (1x); b) + adverb in negation $(2 \mathrm{x})^{13}$.

It follows that in a few cases antea modifies more than one part of speech in a clause/sentence. In the following quotations, the relevant part of speech modified by antea $\bar{a}$ is underlined.

\section{[3.1] A Finite Verb in Past Tenses}

\section{[3.1.1] Perfect}

Igitur Sinnaces, quem anteā infensum memoravi, patrem Abdagaesen aliosque occultos consilii et tunc continuis cladibus promptiores ad defectionem trahit.

"Therefore, Sinnaces, whom I have previously mentioned as being hostile (to Artabanus), drew into revolt his father Abdagaeses, as well as others privy to (his) plot and then more eager (to fight) because of (their) continuous (Parthian) defeats" (Tac. Ann. 6,36,2).

\subsubsection{1 + Adverb}

Plus socordiae quam fiduciae accessisse victoribus; neque enim in procinctu et castris habitos: per omnia Italiae municipia desides, tantum hospitibus metuendos, quanto ferocius anteā egerint, tanto cupidius insolitas voluptates hausisse.

"(Antonius Primus said that) carelessness rather than confidence has grown upon the victors, for they have not been kept in fighting trim nor in a camp, (billeted) in idleness in all the towns of Italy (and) fearful only to their hosts. The more ferociously (the victors) have conducted before, with more eagerness they have drunk of (their) unaccustomed pleasures" (Tac. Hist. 3,2,1).

Ferocius modifies egerint, while anteā modifies ferocius + egerint. Hence, the emphasis is put on egerint (referring to victores), which is modified by both adverbs. Primary tenses are interposed in this speech among secondary ones: egerint for egissent (Wellesley 1972: 78).

\footnotetext{
${ }^{11}$ Some adverbs can be connected with any tense, mainly adverbs of manner, e.g., sapienter, whereas certain tenses are incompatible with certain adverbs of time, such as anteā, heri (Pinkster 1972: 39, 80).

${ }^{12} \mathrm{Cf}$. measure adverbs, which modify an adjective, adverb or verb; manner adverbs, which modify an adjective, verb, etc. On adverbs, which modify an adjective or another adverb see Leumann et al. 1963, 1964 1: 170-172, §101a-c, Löfstedt 1967: 104-108, Pinkster 1972: 59, Menge 2000: 198, §148.

${ }^{13}$ An adverb, which modifies a noun, is rare in Latin and is partially under Greek influence, where it is more prevalent. This usage occurs mainly in poetry and is common since Livius (see Kühner and Stegmann 1962, 2/1: 218-220, §59, Leumann et al. 1963, 1964 1: 171, §101,b).
} 
3.1.1.1.1 In the Clause before $\underline{u t}$ ante $\bar{a}$

Drusoque pridem extincto, Nero solus e privignis erat, illuc cuncta vergere: filius, collega imperii, consors tribuniciae potestatis adsumitur omnesque per exercitus ostentatur, non obscuris, ut anteāa, matris artibus, sed palam hortatu.

"Since Drusus had long been dead, (Tiberius) Nero survived alone of (Augustus') stepchildren and everything converged on him. He was adopted (by Augustus) as (his) son, as colleague in the empire, as partner of the tribunician power, and he was paraded through all the armies, not as before by his mother's secret machinations, but with her open encouragement" (Tac. Ann. 1,3,3).

In the concise form $u t$ ante $\bar{a}$, which is embedded in the comparison clause non ... artibus, ante $\bar{a}$ modifies non + ostento in the perfect (implied from the historical present ostentatur of the main clause omnesque ... ostentatur + sed ... hortatu [referring to the subject Tiberius Nero]).

\section{[3.1.2] Pluperfect + Adverb}

Tac. Hist. 4,75,2, $\$ 4.3 .2$ below. In the relative clause (quis ... consederat) ante $\bar{a}$ modifies temere + consederat with emphasis on consederat, which is also modified by temere. Consederat is in p.q.p., since the army had settled in an unprotected camp before they fortified it.

\section{[3.1.3] Imperfect}

Interea magna vis accusatorum in eos inrupit, qui pecunias faenore auctitabant adversum legem dictatoris Caesaris, qua de modo credendi possidendique intra Italiam cavetur, omissa $<m>$ olim, quia privato usui bonum publicum postponitur. Sane vetus urbi faenebre malum et seditionum discordiarumque creberrima causa, eoque cohibebatur antiquis quoque et minus corruptis moribus. Nam prīmō duodecim tabulis sanctum, ne quis unciario faenore amplius exerceret, cum anteā ex libidine locupletium agitaretur; dein rogatione tribunicia ad semuncias redactu< $\langle m>$; postremo vetita versura.

"Meanwhile, a large army of accusers burst upon those, who habitually increased their money by usury, contrary to the law of the dictator Caesar, by which measures are taken concerning the credit and possessions within Italy, (a law) obsolete long ago, since the public good is subordinated to private interest. The evil of usury was indeed long-standing for Rome and a most frequent cause of seditions and discords, and it was therefore repressed even in ancient times and when morals were less corrupt. For at first it was determined by the Twelve Tables ${ }^{14}$, that no one should lend at interest of more than twelfth per cent, whereas previously (the rate of the interest) was set by the fancy of the rich; subsequently, by a bill brought in by the tribunes, interest was reduced to half that amount (and) finally compound interest was entirely forbidden" (Tac. Ann. 6,16,1-2).

${ }^{14}$ Tacitus ascribes this specific enactment to the Twelve Tables in 450 B.C. (see, e.g., Koestermann 1965, II: 278, Martin 2001: 136). 
See also Tac. Ann. 6,11,1, §4.1.2, ex. 1 below: anteā modifies deligebatur of the main clause (namque ... magistratibus + in tempus deligebatur; its final clause is ne ...foret).

\section{[3.2] Participium in P.P.P.}

\section{[3.2.1] P.P.P. replaces a clause}

(1) Saevitiam annonae incusante plebe statuit frumento pretium, quod emptor penderet, binosque nummos se additurum negotiatoribus in singulos modios. Neque tamen ob ea parentis patriae delatum et anteā vocabulum adsumpsit, acerbeque increpuit eos, qui divinas occupationes ipsumque dominum dixerant.

"When the commons complained of the cruel dearness of the corn, (Tiberius) fixed a price for grain, which the purchaser should pay, (promising) the merchants that he himself would add two sesterces for each individual measure. However, (Tiberius) did not accept on that account the title "Father of the Nation", which had also been offered (to him) before, and he severely rebuked those who called his occupations as "divine" and himself as "lord"" (Tac. Ann. 2,87,1).

The phrase $e t^{15}$ ante $\bar{a}$ (in which et modifies anteā) modifies delatum (replacing a relative clause of the OD vocabulum).

(2) Sed Nero lenti sceleris impatiens minitari tribuno, iubere supplicium veneficae, quod, dum rumorem respiciunt, dum parant defensiones, securitatem morarentur. Promittentibus dein tam praecipitem necem, quam si ferro urgeretur, cubiculum Caesaris iuxta decoquitur virus cognitis anteā venenis rapidum.

"But Nero, impatient of the slow crime, threatened the tribune and ordered the execution of the poisoner (Locusta), on the ground that while (the tutors) were regarding for rumor (and) preparing (their) defences, they were delaying (his) security. When (the tutors) then promised (Nero) that death (should be) so precipitate, as if (one) was pressed by a sword (stroke), a rapid poison of previously tested toxins was concocted next to the bedroom of the emperor (Nero)" (Tac. Ann. 13,15,5).

See also Tac. Hist. 3,58,3, §2.1.1.1.1 above: anteā modifies aspernatus (replacing a relative clause of the $\mathrm{S}$ Vitellius); 4,86,2, §4.2.1, ex. 2: antea modifies usurpata (referring to the OD munia imperii).

\section{[3.2.2] P.Q.P. Pass. (without esse) in the clause before quam ante $\bar{a}$}

Eodem anno saepius audita vox principis, parem vim rerum habendam a procuratoribus suis iudicatarum, ac si ipse statuisset. Ac ne fortuito prolapsus videretur, senatus quoque consulto cautum plenius quam anteà et uberius.

\footnotetext{
${ }^{15}$ According to Heraus 1929: 33, et instead of etiam is rare in Cicero and is used only with certain combinations of words and pronouns (et nunc, simul et, et ipse/ille, etc.).
} 
"In the same year the emperor's statement was more often heard, that legal decisions (judged) by his procurators should have the same force, as if he himself had determined (them). And lest (this opinion) should be regarded that (the princeps) had fortuitously been stumbled, (this) was also secured by a senate's decree more expansively and more copiously than (it had been secured) before" (Tac. Ann. 12,60,1).

Cautum in the main clause (senatus ... plenius + et uberius) in perf. pass. (est) is posterior to the action implied with ante $\bar{a}$ in the comparison clause quam anteā in p.q.p. pass. (erat).

\section{[3.3] Adjective}

\section{[3.3.1] Attribute}

Ubique lamenta, conclamationes et fortuna captae urbis, adeo ut Othoniani Vitellianique militis invidiosa antea à petulantia desideraretur.

"Everywhere (were) lamentations, wailings and the misfortune of the captured city, so that the licence of Otho's and Vitellius' soldiers, once odious, was longed" (Tac. Hist. 4,1,3).

In the consecutive clause (adeo ut ... desideraretur) antea modifies invidiosa. See also Tac. Ann. 4,2,1, §4.2.1, ex. 3 (antea modifies the adjective modicam of the OD vim [the subject is Sejanus]); 6,1,2, $\$ 4.2 .1$, ex. 5 (antea modifies the adjective ignota of the subject vocabula).

\section{[3.3.2] Praedicativum in the clause before quam ante $\bar{a}$}

See Tac. Ann. 12,50,2, §2.2 above: in the comparison clause quam ante $\bar{a}$ the adverb modifies the praedicativum truculentus in positive, which is mentioned in the main clause in comparative truculentior (the subject of both clauses is Radamistus).

\section{[3.3.3] Predicate noun with the copula esse}

See Tac. Ann. 14,28,1, $\$ 4.4$ below: antea modifies the predicate nouns vacuum solutumque + the copula fuerat (referring to the subject $i d$ ).

[3.4] Inf. Perf. Pass. (without esse): Predicate of AcI

\section{[3.4.1] + Inf. complement}

Tac. Ann. 14,20,2, 44.1 .2 , ex. 2 below: antea $\bar{a}$, which refers to ludos edi solitos in AcI (governed by ferrent), modifies the predicate solitos (without esse) + its inf. complement $e d i$.

\section{[3.4.2] + Adverb in negation}

See Tac. Hist. 3,37,2, §2.1.2.1 above: anteā modifies numquam, while the whole phrase numquam anteā refers to alium suffectum in AcI (governed by adnotabant) and modifies its predicate suffectum; Ann. 16,3,2, §2.1.1.1.2 above: antea refers to non falsa somnia sua in AcI (governed by admirans) with emphasis on the modified predicate non falsa. 
Table 3. The Part of Speech Modified by Antea in Descending Order

\begin{tabular}{|c|c|c|c|}
\hline The Part of Speech & References & $\begin{array}{l}\text { No. of } \\
\text { Cases }\end{array}$ & Total \\
\hline $\begin{array}{l}\text { Finite verb in past tenses } \\
\text { Perfect } \\
+ \text { adverb } \\
\text { In the clause before } \underline{u t} \underline{\text { ante}} \bar{a}\end{array}$ & $\begin{array}{l}\text { Tac. Ann. } 6,36,2 \\
\text { Tac. Hist. 3,2,1 } \\
\text { Tac. Ann. 1,3,3 }\end{array}$ & $\begin{array}{l}1 \\
1 \\
1\end{array}$ & \\
\hline Imperfect & Tac. Ann. $6,11,1 ; 16,1-2$ & 2 & \\
\hline Pluperfect + adverb & Tac. Hist. 4,75,2 & 1 & 6 \\
\hline $\begin{array}{l}\text { Participium in P.P.P. } \\
\text { Replaces a clause }\end{array}$ & $\begin{array}{l}\text { Tac. Hist. } 3,58,3 ; 4,86,2 ; \text { Ann. } \\
2,87,1 ; 13,15,5\end{array}$ & 4 & \\
\hline $\begin{array}{l}\text { P.Q.P. pass. (without esse) in } \\
\text { the clause before quam antea }\end{array}$ & Tac. Ann. $12,60,1$ & 1 & 5 \\
\hline $\begin{array}{l}\text { Adjective } \\
\text { Attribute } \\
\text { Praedicativum in the clause } \\
\text { before quam ante } \bar{a} \\
\text { Predicate noun with esse }\end{array}$ & $\begin{array}{l}\text { Tac. Hist. 4,1,3; Ann. 4,2,1; } \\
6,1,2 \\
\text { Tac. Ann. 12,50,2 } \\
\text { Tac. Ann. } 14,28,1\end{array}$ & $\begin{array}{l}1 \\
1\end{array}$ & 5 \\
\hline $\begin{array}{l}\text { Inf. perf. pass. (without } \text { esse): } \\
\text { predicate of AcI } \\
+ \text { inf. complement } \\
+ \text { adverb in negation }\end{array}$ & $\begin{array}{l}\text { Tac. Ann. 14, 20,2 } \\
\text { Tac. Hist. 3,37,2; Ann. 16,3,2 }\end{array}$ & $\begin{array}{l}1 \\
2\end{array}$ & 3 \\
\hline
\end{tabular}

\section{[4] The Position of anteā in Relation to the Part of Speech Modified by It in the Sentence}

The typical word order in a clause/sentence is subject (+ its modifiers) indirect/direct object - predicate ( + its modifiers). Temporal/negative adverbs and adverbial temporal phrases (such as paulo ante, iam diu) usually precede the modified element. Exceptions to these rules for variety, emphasis, explication, etc. occur in classical Latin prose, chiefly in rhetorical passages and poetry, which are generally used by the following: 1) Metathesis of words in which the adverb occurs after its modified element (apart from monosyllabic words, such as non, vel), the modified element introduces a clause, the verb precedes its subject, etc.; 2) Hyperbaton between the adverb and its modified element; and 3) Proximity of similar words (aliquando ... modo) or opposite ones (antea $\ldots$...nunc) $)^{1 \overline{6}}$.

The position of ante $\bar{a}$ in relation to the modified element was examined by linguistic/stylistic means and contexts (where some message is to be highlighted,

\footnotetext{
${ }^{16}$ See also Marouzeau 1948: 155-161, 1949: 11-33, Kühner and Stegmann 1962, 2/2: 613-614, $\S 246$. On Latin word order and the opinions of researchers on the adverb's position see also Booth 1923, Bos 1967, Pinkster 1972, 1990: 163-188, de Jong 1991, Elerick 1994, Devine and Stephens 2006, Hoffmann 2010.
} 
word order, anaphora, a chiastic structure or a parallel one [mainly by contrasted pairs of words; Fanetti 1978-79]). The interval between the adverb and its modified element was calculated, inter alia, by number of words; this usually ranges from one to three words with exceptions consisting of more words. On the other hand, it is not always possible to find any explanation or an unequivocal explanation on the adverb's position, due to differences in contents and stylistic characteristics between the oratorical and historical works of Tacitus. Latin word order is not fixed in the sentence, despite its freedom. Likewise, the opinions on the position of the adverbs in relation to their modified elements are not uniform.

From Table 4: A. The prevalent position of antea is after the modified element (ten instances): in first position (6x); in second place (2x); in third position and further removed place $(2 \mathrm{x}) ; \mathbf{B}$. In four instances ante $\bar{a}$ appears before the modified element: in second position (1x); in third position and further removed $(3 \mathrm{x})$; C. In five instances ante $\bar{a}$ has two positions concerning the modified elements: 1) in the first position after + ; a) in the first position before $(1 \mathrm{x})$; $b)$ in the second position before $(1 \mathrm{x})$; $\mathrm{c}$ ) in the third position and further removed before $(1 \mathrm{x})$; d) in the second position after $(1 \mathrm{x})$; and 2$)$ in the first position before + in third place and further removed before (1x). Antea is not placed at the end of a sentence, nor does it introduce one. For a detailed classification on its position in a clause with phrases, other adverbs, etc. see $\S \S 4.1-4.4$ below.

\section{[4.1] Anteā before the Part of Speech Modified by It in the Sentence}

\section{[4.1.1] In second position before the modified part of speech}

Tac. Ann. 6,36,2, §3.1.1 above. A. In the relative clause (quem ... memoravi) antea modifies memoravi. The OD quem and the praedicativum infensum, which are governed by memoravi (cf. OLD, p. 1097b, s.v. memoro, 2.b. [w. pred.] "to speak of as"), are also made salient by placing anteā between them. Accordingly, the adverb is in the second position before memoravi of the relative clause with the word order OD (rel. pron.) - temporal adv. - praedicativum - modified V (its subject is the author); B. Due to the length of the main clause (igitur Sinnaces + patrem ... trahit) and in order to juxtapose quem to the antecedent Sinnaces, the relative clause is embedded in its main clause and is not placed after it; $\mathbf{C}$. The adverb in first position after memoravi (viz. igitur Sinnaces, quem infensum memoravi anteā patrem ... trahit) can be interpreted as modifying trahit of the main clause as follows: "therefore Sinnaces, whom I have mentioned as being hostile (to Artabanus), drew before into revolt his father ...".

\section{[4.1.2] In third position and further removed before the modified element}

(1) Per idem tempus L. Piso pontifex ... fato obiit ... namque anteā, profectis domo regibus ac mox magistratibus, ne urbs sine imperio foret, in tempus deligebatur qui ius redderet ac subitis mederetur.

"About the same time L. Piso, the pontiff, died a natural death ... for in former days, when the kings and subsequently the magistrates left Rome, (an official) was temporarily chosen to administer justice and provide for emergencies, lest Rome would be without government" (Tac. Ann. 6,11,1). 
A. The final sentence namque ante $\bar{a}$... mederetur predates the preceding one about L. Piso (per ... obiit ...). However, antea occurs in the second place of the sentence, due to the prepositive particle namque ${ }^{17}$. B. Antea $\bar{a}$ is not placed near the modified verb deligebatur of the main clause (namque ... magistratibus + in tempus deligebatur [its subject is implicit]), since deligebatur is preceded by an abl. absol. (profectis ... magistratibus), as well as an adverbial temporal phrase in tempus (cf. $\$ 4.0$ above) and final clause ne ... foret, indicating circumstances and reasons concerning deligebatur. Consequently, in the main clause, the order occurs as prepositive particle - temporal adv. - abl. absol. - final clause adverbial temporal phrase - modified V.

(2) Quippe erant qui Cn. quoque Pompeium incusatum a senioribus ferrent, quod mansuram theatri sedem posuisset. Nam anteā subitariis gradibus et scaena in tempus structa ludos edi solitos.

"Indeed there were some who recalled that even $\mathrm{Cn}$. Pompeius had been criticized by the elders, because he established a permanent abode of the theater. For previously (they said that) the games had been customarily exhibited with makeshift tiers (of benches) and a stage set up temporarily" (Tac. Ann. 14,20,2).

Antea $\bar{a}$ is preposed to the predicate of AcI solitos (esse) + its inf. complement $e d i$, which are modified by it, for the following reasons: A. The clause nam ante $\bar{a}$... solitos predates the preceding one quippe ... posuisset with a contrast regarding time and content, but antea is in second position of the clause on account of the prepositive particle nam (see n. 17 above); B. Between ante $\bar{a}$ and its modified elements edi solitos are embedded an adverbial temporal phrase in tempus and abl. loci subitariis gradibus et scaena structa with a chiastic structure between the multiple parts (adj.-noun/noun-adj.), for drawing an attention to the places, on which the games had been customarily exhibited before:

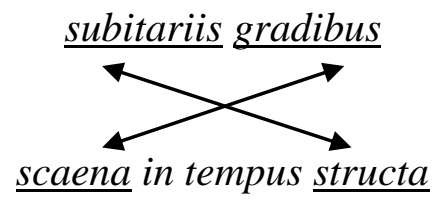

Hence, in the AcI clause nam ... solitos appears the order: prepositive particle - temporal adv. - chiastic abl. loci - adverbial temporal phrase [before structa] AcI (with its modified elements).

(3)Tac. Ann. 6,16,1-2, §3.1.3 above. Anteā does not occur before the modified verb agitaretur (sc. cum ex ... locupletium antea agitaretur) for the following

\footnotetext{
${ }^{17}$ The prepositive particles nam, namque, etc. are regularly placed at the beginning of a clause/ sentence (see Tac. Hist. 3,37,2, §2.1.2.1; Ann. 6,16,1-2, §3.1.3 above; 14,20,2, §4.1.2, ex. 2; $28,1, \S 4.4)$.
} 
reasons: A. The phrase in abl. instr. ex libidine locupletium is embedded between ante $\bar{a}$ and agitaretur for highlighting by whom the rate of the interest was set in the past; B. The temporal clause cum ... agitaretur, in which ante $\bar{a}$ is included, predates the main clause nam ... exerceret with contrast regarding time and content, which is made salient by a contrasting parallel word order between their multiple parts (adv. + abl. instr.): primo $\neq$ ante $\bar{a}$ (while ante $\bar{a}$ is anterior to primo); duodecimo tabulis $\neq$ ex libidine locupletium, i.e. previously the rate of the interest was set up by the fancy of the rich, but later by the Twelve Tables. Accordingly, in the temporal clause cum ... agitaretur the word order occurs as temporal conj. - temporal adv. - abl. instr. - modified V (its subject is faenus):

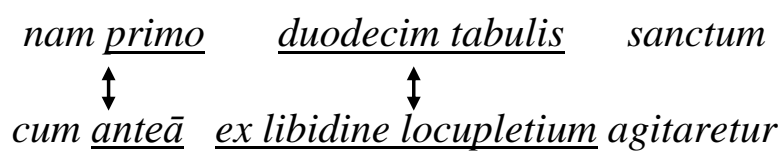

\section{[4.2] Antea after the Part of Speech Modified by It in the Sentence}

\section{[4.2.1] Antea in first position following the modified part of speech}

(1) Tac. Hist. 3,58,3 (see $\$ 2.1 .1 .1 .1$ above). A. In the clause aspernatus antea $\bar{a}$ occurs the word order: modified P.P.dep. (referring to the subject Vitellius; its $\mathrm{OD}$ is nomen) + temporal adv. and not vice versa (i.e. ... voluit ante $\bar{a}$ aspernatus), since antea before aspernatus may modify voluit in an unpunctuated text as follows: "moreover, (Vitellius) even formerly wished to be called Caesar, (a title), which he had rejected ..."; B. Chiastic structures emphasize the following contrasts: a. Between time and content, which describe two different situations concerning the acception of this title: $\boldsymbol{\alpha}$ ) (Nomen) aspernatus ante $\bar{a} \neq$ sed tunc superstitione nominis (voluit), in which antea $\neq$ tunc, (nomen) aspernatus $\neq$ nominis (voluit); $\boldsymbol{\beta})$ Quin ... voluit $\neq$ aspernatus antea a, i.e. aspernatus $\neq$ voluit (without an additional contrasting adverb to anteā); b. Between content only: consilia prudentium $\neq$ volgi rumor $(\mathrm{S}+$ adj. in gen./adj. in gen. $+\mathrm{S})$ :
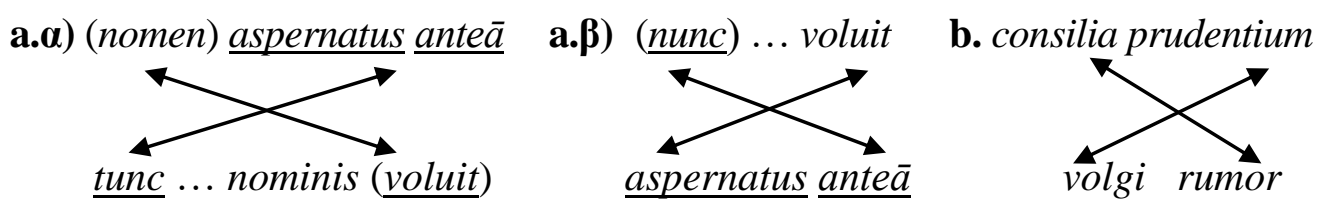

(2) Domitianus sperni a senioribus iuventam suam cernens modica quoque et usurpata anteā munia imperii omittebat.

"Domitian, realizing that his youth is despised by the older (men), had abandoned the imperial duties, which had been previously exercised, even the less important (functions)" (Tac. Hist. 4,86,2).

A. For highlighting the fact that the imperial duties had been previously exercised, ante $\bar{a}$ is embedded in the discontinuous nominal phrase usurpata munia imperii and in the first place after the modified element usurpata. By 
this word order, the combination usurpata antea is juxtaposed to the OD munia imperii and also to its adj. modica (which is strengthened by pleonasm of measure adverbs quoque et "even"); B. Anteā after the OD (viz. modica ... usurpata munia imperii anteā omittebat) may modify omittebat as follows: "Domitian had previously abandoned the imperial duties, which had been exercised, even the less important (functions)"; C. Therefore, in the main clause Domitianus + modica ... omittebat (after AcI) occurs the order: $\mathrm{S}$ - adj. of OD + pleonasm by measure adv. - modified P.P.P. (replaces a rel. clause of the OD) - temporal adv. - OD - V.

(3) Vim praefecturae modicam anteā intendit, dispersas per urbem cohortes una in castra conducendo, ut simul imperia acciperent, numeroque et robore et visu inter se fiducia ipsis, in ceteros metus oreretur.

"(Sejanus) had strengthened the previously modest power of his prefecture by gathering the cohorts scattered throughout Rome in one camp, in order that they would simultaneously receive the orders, and that their confidence would grow by their number, strength and mutual sight, while fear (would be inspired) in others" (Tac. Ann. 4,2,1).

A. Antea modifies the adjective modicam by metathesis of words (cf. $\S 4.0$ above): a. The adverb is placed after modicam. b. The adjective modicam occurs after its noun vim, contrary to the regular word order in Latin, and not vice versa (sc. modicam vim praefecturae anteā intendit), because the adverb may modify intendit with hyperbaton between ante $\bar{a}$ and its modified adj. modicam as follows: "(Sejanus) had previously strengthened the modest power of his prefecture". According to Koestermann 1965, II: 36, vim is more emphasized by its occurrence before modicam; B. On the other hand, in the following clause dispersas ... conducendo, which describes the preceding one vim ... intendit (sc. by which manner Sejanus had strengthened the previously modest power of his prefecture), the adjective precedes its noun by a chiastic structure between both clauses (noun-adj./adj.-noun):

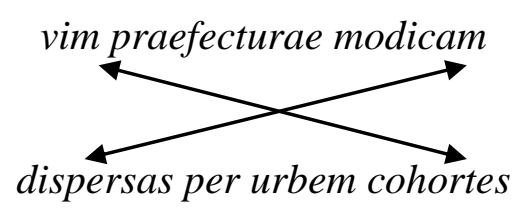

C. Therefore, in the main clause (of a final sentence) vim ... intendit the order is OD (+ modifier in gen.) - modified adj. of the OD - temporal adv. - V.

(4) Tac. Hist. 4,1,3, §3.3.1 above. A. The adjective invidiosa, as well as the phrase in genitive Othoniani Vitellianique militis, are placed before their noun petulantia with the typical word order in Latin. However, the adjective invidiosa, which is modified by ante $\bar{a}$, has an emphatic position, due to its occurrence before ante $\bar{a}$ and not before the phrase in genitive; B. Ante $\bar{a}$ is embedded between the modified adj. invidiosa and its subject petulantia and in 
first position after invidiosa. In this manner, the subject petulantia is near its predicate desideraretur; C. If the adverb is in second position after invidiosa (sc. invidiosa petulantia anteā desideraretur), it will apparently modify desideraretur "the odious licence was longed before" with hyperbaton between the subject petulantia and its predicate desideraretur; D. Accordingly, in the consecutive clause adeo ut ... desideraretur the word order consecutive conj. gen. (of the S) - modified adj. (of the S) - temporal adv. - S - V occurs.

(5) Nec formam tantum et decora corpora, sed in his modestam pueritiam, in aliis imagines maiorum incitamentum cupidinis habebat. Tuncque prīmum ignota anteā vocabula reperta sunt sellariorum et spintriarum ${ }^{18}$ ex foeditate loci ac multiplici patientia.

"Nor merely beauty and handsome bodies, but (also) the modest childhood in some, (and) in others the images of their ancestors were an incitement of (Tiberius') lust. And then for the first time were invented the previously unknown names of "sellarii" and "spintriae", (derived) from the abomination of the place and the multiple phases of sensuality respectively" (Tac. Ann. $6,1,2)$.

A. Antea occurs between the modified adjective ignota and its subject vocabula and not after the whole phrase ignota vocabula (sc. ... ignota vocabula antea reperta sunt ...), in order to avoid hyperbaton between the subject vocabula and its predicate reperta sunt. Likewise, ante $\bar{a}$ in this case may modify reperta sunt; B. If ante $\bar{a}$ is in first position before ignota (i.e. tuncque primum ante $\bar{a}$ ignota vocabula ...), different adverbs denoting time will appear in succession, which makes the context clumsy; C. A contrasting chiastic structure occurs between the adverbs's time (in which tuncque primum is posterior to ante $\bar{a}$ ) and the content of their modified elements, i.e. the names were unknown before (ignota anteā) and later were invented the names "sellarii" and "spintriae" (tuncque primum reperta sunt):

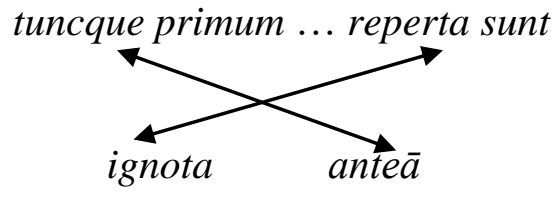

D. The grammatical subject vocabula refers to both contrasted parts mentioned above. In order vocabula will be near its predicate reperta sunt and also near the names sellariorum et spintriarum mentioned after reperta sunt - vocabula is mentioned before reperta sunt and not after tuncque primum (sc. tuncque primum vocabula ignota antea reperta sunt). Hence, there is hyperbaton between tuncque primum and its modified verb reperta sunt with the insertion of ignota antea $\bar{a}$ between them; E. Regarding content, the sentence tuncque ... patientia is connected with the preceding one nec formam ... habebat, while the following

\footnotetext{
${ }^{18}$ On the names sellariorum and spintriarum see, e.g., $O L D$, p. 1728c, s.v. sellarius, p 1805b, s.v. spintria; Martin 2001: 112, Woodman 2017: 90-92.
} 
clause ex foeditate ... patientia in abl. causae explains the names sellariorum et spintriarum mentioned in tuncque ... spintriarum; $\mathbf{F}$. Therefore, in the multiple sentence tuncque primum ... patientia occurs the structure: adverbial temporal phrase - modified adj. (of the S) - temporal adv. - S - V - multiple parts in gen. (of the $S$ ) - multiple phrases in abl. causae (ex foeditate ... patientia).

(6) Tac. Ann. 13,15,5, §3.2.1, ex. 2 above. A. The topic of the sentence concerns the poisoner Locusta. The phrase cognitis antea venenis in abl. materiae, in which antea modifies cognitis (referring to venenis), qualifies virus rapidum with the insertion of cognitis antea venenis between virus and rapidum. In this manner, the phrase virus rapidum has an emphatic meaning in the past; B. The adverb in the second position before cognitis (i.e. ... decoquitur ante $\bar{a}$ virus cognitis venenis ...) may be interpreted as modifying decoquitur; $\mathbf{C}$. Hence, in the main clause (of the AcI) cubiculum ... rapidum the order is acc. of place (by anastrophe of a preposition) - V - S - modified P.P.P. (of abl. materiae) temporal adv. - abl. materiae - adj. (of the $S$ ).

\section{[4.2.2] Antea in second position following the modified part of speech}

(1) Tac. Ann. 12,50,2, §2.2 above. A. Stylistically and regarding content, the comparison clause quam ante $\bar{a}^{19}$ can not occur before the main clause vacuamque ... truculentior + tamquam ... <re >bellaturos (namely quam antea vacuamque ... truculentior ...; cf. Tac. Ann. 12,60,1, §3.2.2 above); B. Quam ante $\bar{a}$ is embedded in the main clause, in order that ante $\bar{a}$ will be near the modified element truculentus in positive, which is implied from truculentior of the main clause (its subject is Radamistus). By this word order, the contrast between the comparison clause with positive form in the past and the main clause with comparative form in the present is emphasized. Accordingly, in the comparison clause quam antea the structure is comparison conj. - temporal adv. (+ modified praedicativum in posit. truculentus, implied from truculentior).

(2) Tac. Ann. 2,87,1, §3.2.1, ex. 1 above. A. According to Lundeström (1961: 81-83); Menge (2000: 507, §380,3), in several cases anteā (instead of ante) occurs after an adverb indicating measure (mainly in ablative) and seldom before it (cf. a similar word order with ante: paulolet ante, etc.). In this case, the measure adverb et modifies anteā and occurs before it, while et + antea modify delatum; $\mathbf{B}$. The phrase delatum et antea is an attribute to the OD parentis patriae vocabulum with its insertion between parentis patriae and vocabulum, while antea is in second position after delatum. If the adverb is in third place after delatum (sc. neque ... delatum et vocabulum anteā adsumpsit), only et will modify delatum, whereas neque + anteā will modify adsumpsit: "however, (Tiberius) did not accept before on that account the title "Father of the Nation", which had also been offered (to him)". C. Therefore, in the attribute phrase delatum et antea of the OD occurs the word order: modified P.P.P. (of the OD vocabulum; the grammatical subject is Tiberius) - measure adv. - temporal adv.

\footnotetext{
${ }^{19}$ For quam antea (rarely instead of ante) in other corpora cf. L.-Sh., p. 129b, s.v. antea $\bar{a}$, temp. adv., IV; OLD, p. 138b , s.v. anteā, adv., d.; TLL 1/2, p. 139, s.v. anteāa, II. See also under antequam.
} 


\subsubsection{Antea in third position following its modified part of speech}

(1) Tac. Ann. 12,60,1, §3.2.2 above. Stylistically and regarding content, quam antea $\bar{a}$ can not occur before the main clause senatus ... plenius + et uberius (sc. quam anteā senatus ... plenius et uberius; cf. Tac. Ann. 12,50,2, $\$ 2.2$ above). Likewise, it does not occur after its main clause, but it is embedded in it. In this manner: 1) Antea is near the modified verb cautum, but in p.q.p. pass., which is implied from cautum (est) in perf. pass. of the main clause (its $\mathrm{S}$ is vox pricipis) with the word order: comparison conj. - temporal adv. (+ modified V cautum [erat]), implied from cautum [est]); 2) The contrast between both clauses is made salient, since cautum (est) of the main clause is emphasized by adverbs in comparative plenius et uberius.

(2) Tac. Ann. 1,3,3, §3.1.1.1.1 above. A. A chain of events, in which the status of Tiberius Nero was changed, is described in the comparison clause (non ... artibus) and the main clause (omnesque ... ostentatur + sed palam hortatu) by a contrasting parallel structure with respect to time (without an additional contrasting adverb to antea $)$ and content (between their adjectives obscuris $\neq$ palam $^{20}$ and nouns artibus $\neq$ hortatu), namely non (ostentavit) $+u t$ antea refer to obscuris artibus of the comparison clause in contrast to ostentatur, which refers to sed palam hortatu of the main clause:

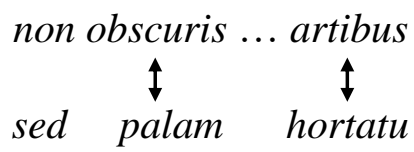

B. Stylistically and regarding content, $u t$ antea cannot occur before the main clause (sc. ut anteā ostentatur, non obscuris ... artibus, sed palam hortatu), but it is embedded in the main clause; C. Consequently, in the comparison clause non ... artibus occurs the construction: negative adv. - adj. (of abl. instr.) comparison conj. - temporal adv. - abl. instr - modified $\mathrm{V}$ in neg. (non + ostentavit in perf. [implied from ostentatur in the main clause; its $\mathrm{S}$ is Nero]).

\section{[4.3] Anteā in First Position after +}

\section{[4.3.1] In first position before}

Tac. Hist. 3,2,1 (see \$3.1.1.1 above). Anteā modifies ferocius + egerint (the verb is also modified by ferocius), which are highlighted by the insertion of ante $\bar{a}$ between them and by a parallel structure between quanto ... egerint in correlation to tanto ... hausisse, i.e. correlative particle - manner adverb in comparative - V (referring to victores):

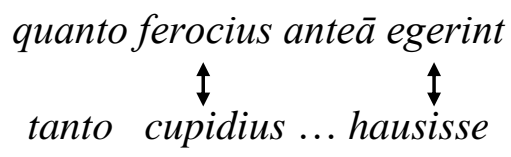

\footnotetext{
${ }^{20}$ The adverb palam functions here as an adjective to hortatu (see, e.g., Goodyear 1972: 113).
} 


\section{[4.3.2] In second position before}

Hostes divisis copiis advenere undique. Plerique culpabant Cerialem passum iungi quos discretos intercipere licuisset. Romanus exercitus castra fossa valloque circumdedit, quis temere anteā intutis consederat.

"The enemy, whose forces were divided, advanced on (Trier) from every quarter. Many blamed Cerialis for allowing (the enemy) to unite, when he might have destroyed them, while they are detached. The Roman army surrounded the camp with a ditch and rampart, which they had previously rashly settled in it, while (the camp) is not fortified" (Tac. Hist. 4,75,2).

A. In the relative clause (quis [for in quibus] ... consederat) antea is embedded between temere and consederat, which are modified by it, in contrast to the main clause Romanus ... circumdedit with respect of time (without an additional contrasting temporal adverb to ante $\bar{a}$ ) and content (the subject of both clauses is Romanus exercitus), sc. the army first settled in an unprotected camp, but later they constructed means of protections. However, the whole relative sentence Romanus ... consederat occurred after the enemy's approach mentioned in the preceding sentence hostes ... licuisset; B. Intutis, praedicativum to castra, appears before consederat, since it emphasizes in which situation the Roman army had previously settled in the camp; C. Consequently, ante $\bar{a}$ is placed in second position before consederat, while in the relative clause quis ... consederat the word order abl. loci (rel. pron.) - modified manner adv. temporal adv. - praedicativum (to the antecedent castra) - modified V occurs.

\section{[4.3.3] In third position and further removed before the modified element}

Tac. Hist. 3,37,2, §2.1.2.1 above. A. The paragraph with ante (nam ... festinarentur) predates the preceding one with antea (pridie ... suffectum), sc. during the time of Rosius Regulus no consul was elected before the office had been declared vacant. Caninius Rebilus was elected as a consul for one day before what is reported about Rosius Regulus. In order that the modified predicate suffectum of the AcI will be near the content of the following paragraph with ante, it appears at the end of the first paragraph (pridie ... suffectum) and not near ante $\bar{a} ; \underline{\mathbf{B}}$. Both abl. absol. in negation non abrogato magistratu and neque lege lata are embedded between numquam antea and the AcI alium suffectum (esse), for drawing attention to circumstances whereby another consul had been elected in the past; $\underline{\mathbf{C}}$. The position of ante $\bar{a}$ after numquam, which is also modified by it, is required logically and stylistically, due to the negative adverbs after antea , which modify the predicates of both abl. absol.: non > abrogato; neque > lata. Likewise, antea before numquam (sc. anteā numquam non abrogato magistratu neque lege ... suffectum) may modify suffectum in affirmative, while numquam may modify non abrogato + neque lata in litotes, due to the occurrence of negative adverbs in succession, and the abl. absol. will also be rendered in affirmative; D. Accordingly, in the AcI clause (adnotabat periti) numquam ... suffectum appears the following word order: modified temporal adv. in neg. - temporal adv. - abl. absol. in neg. (indicating circumstances) - S of AcI - modified pred. of AcI. 


\section{[4.3.4] In second position after}

Tac. Ann. 16,3,2, §2.1.1.1.2 above. A. The predicate of AcI non falsa (esse) occurs after non, since a negative adverb, mainly monosyllabic word, regularly precedes its modified element; B. Non falsa, which is modified by antea $\bar{a}$, is also emphasized by placing ante $\bar{a}$ in first position after it - between non falsa and its subject somnia sua and by a chiastic structure between the adverbs and their modified predicates of both multiple parts non falsa ... sua and seque ... elusum (while tunc prìmum is posterior to anteā):

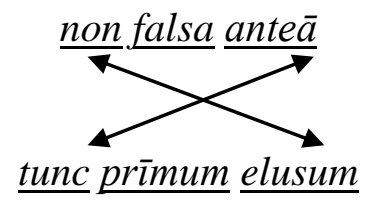

[4.4] In First Position before + in Third Place and Further Removed One before

Auxitque patrum honorem statuendo ut, qui a privatis iudicibus ad senatum provocavissent, eiusdem pecuniae periculum facerent, cuius si qui imperatorem appellare $\langle n t>$; nam anteā vacuum id solutumque poena fuerat.

"(Tiberius) also increased the honor of the senators by ordering that those, who appealed to the senate against private judges, should be liable the risk of the same forfeit as those appealing the emperor; for this (appeal) was previously unrestricted and exempt from penalty" (Tac. Ann. 14,28,1).

A. The clause nam antea $\bar{a}$... fuerat predates the preceding one auxitque ... appellare $\langle n t\rangle$ with a contrast regarding time and content. Due to the prepositive particle nam, ante $\bar{a}$ is in second place of the clause nam ... fuerat (see n. 17 above) and the subject id does not introduce it. However, id is embedded between its both predicate nouns vacuum solutumque, for avoiding hyperbaton between the subject $i d$ and the message mentioned in the preceding clause auxitque ... appellare $\langle n t\rangle$, to which id refers; B. Antea, which modifies vacuum solutumque (poena) + fuerat, does not occur in second position before fuerat (viz. nam vacuum id solutumque anteā poena fuerat), due to the idiom solutus poena "exempt from a penalty". ${ }^{21}$ From the above-mentioned interpretations, ante $\bar{a}$ is in first position before the first predicate noun vacuum + in third position and further removed before the second predicate noun solutumque (poena) and the copula fuerat, while in the multiple clause nam ... fuerat the structure is: prepositive particle - temporal adv. - modified predicate noun (1) - S - modified predicate noun (2) - abl. separativus - modified copula.

${ }^{21}$ See, e.g., L.-Sh., 1728 a - b, s.v. solutus,-a,-um, B.3; OLD, 1790b, s.v. solutus,-a,-um, adj. 10.b. 
Table 4. The Position of Antea in Relation to Its Modified Element in the Sentence

\begin{tabular}{|c|c|c|c|}
\hline The Position of antea $\bar{a}$ & References & $\begin{array}{l}\text { No. of } \\
\text { Cases }\end{array}$ & Total \\
\hline $\begin{array}{l}\text { Before the part of speech } \\
\text { In second position }\end{array}$ & Tac. Ann. 6,36,2 & 1 & \\
\hline $\begin{array}{l}\text { In third position and further } \\
\text { removed place }\end{array}$ & $\begin{array}{l}\text { Tac. Ann. 6,11,1; 16,1-2; } \\
14,20,2\end{array}$ & 3 & 4 \\
\hline $\begin{array}{l}\text { After the part of speech } \\
\text { In first position }\end{array}$ & $\begin{array}{l}\text { Tac. Hist. } 3,58,3 ; 4,1,3 ; 86,2 ; \\
\text { Ann. } 4,2,1 ; 6,1,2 ; 13,15,5\end{array}$ & 6 & \\
\hline In second position & Tac. Ann. 2,87,1; 12,50,2 & 2 & \\
\hline $\begin{array}{l}\text { In third position and further } \\
\text { removed place }\end{array}$ & Tac. Ann. $1,3,3 ; 12,60,1$ & 2 & 10 \\
\hline $\begin{array}{l}\text { In first position after }+ \\
\text { In first position before } \\
\text { In second place before } \\
\text { In third position and further } \\
\text { removed place before } \\
\text { In second position after }\end{array}$ & $\begin{array}{l}\text { Tac. Hist. 3,2,1 } \\
\text { Tac. Hist. 4,75,2 } \\
\text { Tac. Hist. } 3,37,2 \\
\text { Tac. Ann. } 16,3,2\end{array}$ & $\begin{array}{l}1 \\
1 \\
1 \\
1\end{array}$ & 4 \\
\hline $\begin{array}{l}\text { In first position before }+ \text { in } \\
\text { third position before }\end{array}$ & Tac. Ann. $14,28,1$ & 1 & 1 \\
\hline
\end{tabular}

\section{[5] A Comparison of Antea between the Treatises of Tacitus}

Some of our findings, detailed in $\S \S 1-4$ above concerning ante $\bar{a}$, are identical to Hist. and Ann., whereas some are different, due to the contents and the author's style in each book (see Table 5; for references see Tables 1-4).

\section{Identical Features}

Its frequent meaning of "previously, before" and its distribution are almost the same.

Antea occurs in proximity to an additional adverb or without it.

The modified part of speech: a) Is explicit; b) Perfect + adverb; c) P.P.P.; d) Inf. perf. pass. (without esse): predicate of AcI; e) Adjective: attribute.

It is placed in first position after the modified element.

\section{Different Features}

The phrase ut/quam anteā: Ann

The modified part of speech: a) Perfect: Ann.; b) Pluperfect + adverb: Hist.; c) Imperfect: Ann.; d) Adjective: $\alpha$ ) Predicate noun with the copula esse: Ann.; $\beta$ ) Praedicativum: Ann.

The position of antea in relation to the modified element: A. Before the modified element: a) In second position: Ann.; b) In third place and further 
removed position before: Ann.; B. After the modified element: a) In second position: Ann.; b) In third place and further removed: Ann.; C. In first place after +: a) In first/second/third place before: Hist.; b) In second position after: Ann.; D. In first position before + in third position and further removed before: Ann.

Table 5. Anteā - A Comparison between Hist. and Ann. of Tacitus

\begin{tabular}{|c|c|c|c|}
\hline \multirow[t]{2}{*}{ Identical Features } & \multicolumn{2}{|c|}{\begin{tabular}{|l|} 
The \\
Treatise
\end{tabular}} & \multirow[t]{2}{*}{ Total } \\
\hline & Hist. & Ann. & \\
\hline $\begin{array}{l}\text { Its frequent meaning and distribution Antea in proximity to an } \\
\text { additional adverb }\end{array}$ & 6 & 13 & 19 \\
\hline Antea $\bar{a}$ without proximity to an additional adverb & 4 & 8 & 12 \\
\hline The part of speech modified by ante $\bar{a}$ & 2 & 6 & 8 \\
\hline Is explicit & 6 & 13 & 19 \\
\hline Perfect + adverb & 1 & 1 & 2 \\
\hline P.P.P. & 2 & 3 & 5 \\
\hline Inf. perf. pass. (without esse): predicate of AcI & 1 & 2 & 3 \\
\hline Adjective: attribute & 1 & 2 & 3 \\
\hline It is placed in first position after its modified element & 3 & 3 & 6 \\
\hline \multicolumn{4}{|l|}{ Different Features } \\
\hline $\begin{array}{l}\text { The phrase ut/quam ante } \bar{a} \\
\text { The part of speech modified by the adverb }\end{array}$ & - & 3 & 3 \\
\hline Perfect & - & 1 & 1 \\
\hline P.q.p. + adverb & 1 & - & 1 \\
\hline Imperfect & - & 2 & 2 \\
\hline Adjective & & & \\
\hline Predicate noun with the copula esse & - & 1 & 1 \\
\hline Praedicativum & - & 1 & 1 \\
\hline $\begin{array}{l}\text { The position of antea } \bar{a} \text { in relation to the modified element } \\
\text { Ante } \bar{a} \text { before the modified element }\end{array}$ & & & \\
\hline In second position & - & 1 & 1 \\
\hline $\begin{array}{l}\text { In third position or at a further removed position before } \\
\text { The adverb after the modified element }\end{array}$ & - & 3 & 3 \\
\hline In second position & - & 2 & 2 \\
\hline In third position or at a further removed & - & 2 & 2 \\
\hline In first position after + : & & & \\
\hline In first/second/third position and further removed before & 3 & - & 3 \\
\hline In second position after & - & 1 & 1 \\
\hline In first place before + in third place and further removed before & - & 1 & 1 \\
\hline
\end{tabular}

\section{[6] Conclusions}

Antea occurs only in Ann. and Hist., whereas in the minor books it is not documented. It is used for one description as a temporal adverb with the meaning "previously, before" in different contexts, whereas other synonymous adverbs with ante $\bar{a}$ are used as: 1) An adverb or adjective; 2) An adverb of time or place; 3 ) Or for more than one meaning. Its variants appear mainly with 
ante (instead of anteā). Anteā occurs in proximity to an additional adverb, mostly with contrasting temporal adverbs denoting posteriority/anteriority in relation to the past with antea , and rarely with negative/manner/measure adverb.

The modified part of speech by anteā: 1) is only explicit; and 2) is mentioned in the clause, in which antea $\bar{a}$ is included, whereas in three cases the modified element is mentioned before the phrase ut/quam anteā. 3) The grammatical forms modified by the adverb are mostly a finite verb in past tenses, due to the meaning of antea (perfect, imperfect, pluperfect [+adverb]), participium in P.P.P., adjective and infinitive as a predicate of AcI [+ adverb]. In a few cases, antea modifies more than one part of speech in a clause/sentence.

The position of ante $\bar{a}$ in relation to the modified part of speech: 1) Its prevalent position is after the modified element: in the first/second/third position and further removed place; 2) Ante $\bar{a}$ sometimes appears before the modified element: in the second/third position and further removed place; 3) In some instances ante $\bar{a}$ has two positions concerning the modified elements: either a) in the first position after $+: \alpha$ ) in first/second/third position and further removed before; $\beta$ ) in second position after; or $b$ ) in the first place before + in third position and further removed before; 4) Antea is not placed at the end of a sentence nor does it introduces one.

A concluding comparison of antea between Tacitus' books is essential. Indeed, his books have somewhat difference in content and style, which naturally creates differences in the use of antea and the contexts in which it occurs. However, the comparison yielded identical and different features.

\section{References}

Blackman DR, Betts GG (1986) A Concordance to Tacitus. Concordantia Tacitea 1. Hildesheim, Zurich \& New York: Olms-Weidmann.

Booth BE (1923) The Collocation of the Adverb of Degree in Roman Comedy and Cato. Doctoral Dissertation, University of Chicago, Chicago.

Bos GE (1967) L'adverbe en Latin. Tentative de classification structurale (The Adverb in Latin. Attempt of Structural Classification). Bulletin de la Société de linguistique de Paris 62: 106-122.

Calboli G (1965) La sinonimia latina fino alla prosa classica (The Latin Synonymy up to the Classical Prose). Quaderni dell'Istituto di Glottologia di Bologna 8: 21-66.

Calboli G (1989) La synonymie dans la pratique et dans la théorie grammaticale et rhétorique (The Synonymy in Practice and in the Grammatical and Rhetorical Theory). Ktema 14: 169-180.

Devine AM, Stephens LD (2006) Latin Word Order: Structured Meaning and Information. Oxford: Oxford University Press.

Draeger A (1882) Ueber Syntax und Stil des Tacitus (On Syntax and Style of Tacitus) (3rd Edn.). Leipzig: BG Teubner (repr. Amsterdam: AM Hakkert, 1967).

Elerick C (1994) How Latin Word Order Works. In G Calboli (Eds.), Papers on Grammar IV. Rome: Herder, pp. 99-117.

Fanetti D (1978-79) Il Chiasmo nell'Agricola di Tacito (The Chiasmus in Agricola of Tacitus). Museum crticum 13-14: 389-400. 
Fisher CD (1906) Cornelii Taciti Annalium. Ab Excessu Divi Augusti Libri (The Annals of Cornelius Tacitus.The Books from the Death of Augustus onwards). Oxford Classical Texts. Oxford: Oxford University Press.

Fisher CD (1911) Cornelii Taciti Historiarum Libri (The Histories of Cornelius Tacitus). Oxford Classical Texts. Oxford: Oxford University Press.

Francis ED (1973) Particularum quarundam varietas: prae and pro (A Variety of Several Particles: prae and pro). In T Cole, D Ross (Eds.), Studies in Latin Language and Literature. Yale Classical Stuies 23. Cambridge: Cambridge University Press, pp. 1-59.

Gerber A, Greef A (1877-1890) Lexicon Taciteum 1. Leipzig: BG Teubner (repr. Hildesheim: G. Olms, 1962).

Goodyear FRD (1972) The Annals of Tacitus I: Annals 1, 1-54. Cambridge Classical Texts and Commentaries 15. Cambridge: Cambridge University Press (repr. 2004).

Heraeus K (1929) Cornelii Taciti Historiarum Libri Qui Supersunt II, Buch 3-5 (Tacitus Volume 2, Book 3-5) (4 ${ }^{\text {th }}$ Edn.). Leipzig-Berlin: BG Teubner (repr. Amsterdam: AM Hakkert, 1966).

Heubner H (1978) P. Cornelii Taciti Libri Qui Supersunt 2/1. Historiarum Libri (Tacitus, Histories, Volume 2/1) (1st Edn.). Bibliotheca Scriptorum Graecorum et Romanorum Teubneriana. Stuttgart: BG Teubner.

Heubner H (1994) P. Cornelii Taciti Libri Qui Supersunt 1. Ab Excessu Divi Augusti (Tacitus Volume 1: from the Death of Augustus onward). Bibliotheca Scriptorum Graecorum et Romanorum Teubneriana. Stuttgart: BG Teubner.

Hoffmann R (2010) Latin Word Order Revisited: Information Structure of Topic and Focus. In P Anreiter, M Kienpointer (Eds.), Latin Linguistics Today. Akten 15th International Colloquium on Latin Linguistics Innsbruck, 4-9 April 2009, Innsbruck: Institut für Sprachen und Literaturen der Universität Innsbruck, pp. 267-279.

de Jong JR (1991) Word order in Cato's De Agricultura. In J Herman (Edn.), Linguistic Studies on Latin. Selected Papers from the 6th International Colloquium on Latin Linguistics, Budapest, 23-27 March 1991. Studies in Language Companion 28. Amsterdam-Philadelphia: J. Benjamins, pp. 91-101.

Koestermann E (1965) Cornelius Tacitus, Annalen II, Buch 4-6 (Cornelius Tacitus, Annals II, 4-6). Heidelberg: C Winter.

Koestermann E (1969) P. Cornelii Taciti Libri Qui Supersunt II/2: Historiarum Libri (Tacitus Volume 2/2: Histories). Bibliotheca Scriptorum Graecorum et Romanorum Teubneriana. Leipzig: BG Teubner.

Koestermann E (1971) P. Cornelii Taciti Libri Qui Supersunt I: Ab Excessu Divi Augusti (Tacitus Volume 1: from the Death of Augustus onwards) (3rd Edn.). Bibliotheca Scriptorum Graecorum et Romanorum Teubneriana. Leipzig: BG Teubner.

Kühner R, Stegmann C (1962) Ausfürliche Grammatik der Lateinischen Sprache (Detailed Grammar of the Latin Language) 2/1, 2/2. Satzlehre 4th Edn. Munich: M. Hueber.

Leumann E, Hofmann JA, Szantyr A $(1963,1964)$ Lateinische Syntax und Stilistik (Latin Syntax and Stylistics). Handbuch der Altertumswissenschaft, II, 2/2 (Handbook of Archeology, II, 2/2). Munich: CH Beck.

Lewis CT, Short C (1879) A Latin Dictionary. Oxford: Clarendon Press (repr. 1996).

Löfstedt B (1967) Bemerkungen zum Adverb im Lateinischen (Remarks on the Adverb in Latin). Indogermanische Forschungen 72: 79-109.

Lundström S (1961) Abhinc und Ante: Studien zur Geschichte der Lateinischen Zeitdifferenzbestimmungen (Abhinc and Ante: Studies on the History of the Latin 
Designations of Time Difference). Acta Reg. Humane Societatis Humaniorum Literarum Lundensis 62. Lund: CW K Gleerup.

Marouzeau J (1948) Quelques vues sur l'ordre des mots en latin (Some Views on Latin Word Order). Lingua 1: 155-161.

Marouzeau J (1949) L' ordre des mots dans la phrase Latine. Les Articulations L'Énoncé 3 (The Order of the Words in the Latin Phrase. Articulations of the Statement 3). Collection d'études latines publiée par la Société des Études Latines (Collection of Latin Studies published by the Society of Latin Studies. Scientific Series) 24. Paris: Les belles lettres.

Martin R (2001) Tacitus: Annals V \& VI. Warminster: Aris \& Phillips.

Mendell CW (1911) Sentence Connection in Tacitus. Doctoral Dissertation, Yale University. New Haven.

Menge H (1961) Repetitorium der Syntax und Stilistik (Review of Syntax and Stylistics) (16th Edn. reworked by A Thierfeld). Münich: M Hueber.

Menge H (1988) Lateinishe Synonymik (Latin Synonymic) (7th Edn.). O. Schonberger (Eds.). Heidelberg: C Winter.

Menge H (2000) Lehrbuch der lateinischen Syntax und Semantik (Textbook of Latin Syntax and Semantics). Completely reworked by Th. Burkard, M Shower. Darmstadt: Wissenschaftliche Buchgesellschaft.

Pinkster H (1972) On Latin Adverbs. North-Holland Linguistic Series 6. Amsterdam: North Holland Publishing Company.

Pinkster H (1990) Latin Syntax and Semantics. Translated by Holze Multer. LondonNew York: Routledge.

Risselada R (1996) And Now for Something Completely Different? Temporal Discourse Marks: Latin nunc and English Now. In R Risselada, Jan R De Jong, Machtelt Bolkestein (Eds.), On Latin Linguistic and Literary Studies in Honour of Harm Pinkster. Amsterdam: JC Gleben.

Römer F (1976) P. Corneli Taciti Annalium Libri XV-XVI. Wiener Studien: Journal of Classical Philology and Patristics, Supplement 6. Wien-Köln-Graz: H Böhlau.

Simcox WH (1876) Cornelii Taciti Historiae. Oxford-Cambridge: Rivingtons.

Thesaurus Linguae Latinae (1903) Editus auctoritate et consilio accademiarum quinque Germanicarum, Berolinensis, Gottingensis, Lipsiensis, Monacensis, Vindobonensis (Prices council the Academies old German, Berlin, Gottingen, Leipzig, Munich, Vindobonensis). Leipzig: BG Teubner.

Voss B-R (1963) Der pointierte Stil des Tacitus (The Emphasized Style of Tacitus). Orbis Antiquus 19. Münster: Aschendorff.

Weiskopf H (1973) P. Corneli Taciti Annalium Libri XI-XII. Wiener Studien: Journal of Classical Philology and Patristics. Supplement 4. Wien-Köln-Graz: H Böhlau.

Wellesley K (1972) Cornelius Tacitus, The Histories Book III. Sydney: Sydney University Press.

Woodman AJ (2017) The Annals of Tacitus, Books 5 and 6. Cambridge Classical Texts and Commentaries 55. Cambridge: Cambridge University Press.

Non-Bibliographical Abbreviations

Lewis-Short 1879, p. XII; Glare et al. (Eds.) 1982, pp. XXI-XXIII. 
